DOI: $10.2478 / \mathrm{v} 10025-010-0007-8$

JOURNAL OF WATER

AND LAND DEVELOPMENT

J. Water Land Dev. No. 13b, 2009: 109-123

\title{
Evaluation of the hydrological role of wetlands in the Włodawka River catchment (Polesie Lubelskie)
}

\author{
Marek TURCZYŃSKI, Zdzisław MICHALCZYK, Stanisław CHMIEL, \\ Katarzyna MIĘSIAK-WÓJCIK, Sławomir GŁOWACKI
}

University Maria Curie-Skłodowska, Department of Hydrography, ul. Akademicka 19, 20-033 Lublin, Poland; e-mail: turmar@tlen.pl

\begin{abstract}
The Włodawka River catchment of an area of $725 \mathrm{~km}^{2}$ covers the central and eastern part of the Lęczna-Włodawa Lake District. Evaluation of the role of hydrogenic areas in runoff creation was based on materials of the Department of Hydrography and the Institute of Meteorology and Water Management data. The analysis was conducted for selected catchments in which additional hydrometric measurements and water quality tests were done. Such parameters as: the share of hydrogenic surfaces in total catchment area, types of wetlands, their hypsometric location and position with reference to drainage streams were taken into consideration for evaluation. The degree of anthropogenic transformation of the marshland was expressed in terms of density and depth of the drainage ditches that dissect it. It was found that the drained gyttja of Krowie Bagno plays a considerable role in increasing the minimum discharge. Wetlands in the Włodawka River catchment influence the conditions of the runoff and water quality, which is noticeable, primarily, in the concentration of organic carbon, and of nitrogen and phosphorus compounds.
\end{abstract}

Key words: hydrology, physico-chemical properties, Polesie Lubelskie, wetlands

\section{INTRODUCTION}

The influence of wetlands, particularly peatland, on water resources in rivers has been analysed by many authors, yet the obtained results have failed to provide an explicit answer to the question of their role in river alimentation (CHURSKI, 1993; ILNICKI, 2000). This is due to the specific character of the examined bodies and to the complexity of the peatland drainage system. Polesie Lubelskie is an area where numerous peatlands occur (BOROWIEC, 1990), whose role in river runoff has been described by MICHALCZYK et al. $(1998,1999)$ and LIPKA (2000), among others.

PASZCZYK and TURCZYŃSKI (1996) have shown the essential role of hydrogenic areas in runoff creation in the Łęczna-Włodawa Lake District when analyz- 
ing the transformation of precipitation depending on the forms of land use. During a prolonged period of atmospheric drought, the presence of peatland and gyttja guarantee a permanent functioning of the rivers of Polesie (MICHALCZYK and GŁOWACKI, 2008; MIĘSIAK-WÓJCIK, 2009). The drainage basin of the Włodawka is a standard example of a hydrographic system formed by incorporating numerous drainless areas (SPOSÓB and TURCZYŃSKI, 2009). It is a very attractive object of study in terms of paludological research, including the hydrology of wetlands of high environmental value (Funkcjonowanie..., 1996; Polesie..., 1963).

\section{RESEARCH AREA}

The Włodawka catchment (Fig. 1), of an area of $752 \mathrm{~km}^{2}$, comprises the subregions of Polesie Lubelskie: the Lęczna-Włodawa Lake District and Włodawa Hummock, and of the Lublin Upland: Chełm Hills with the Uhrusk Arc. The central part of the drainage basin, which belongs to the Lęczna-Włodawa Lake Dis-

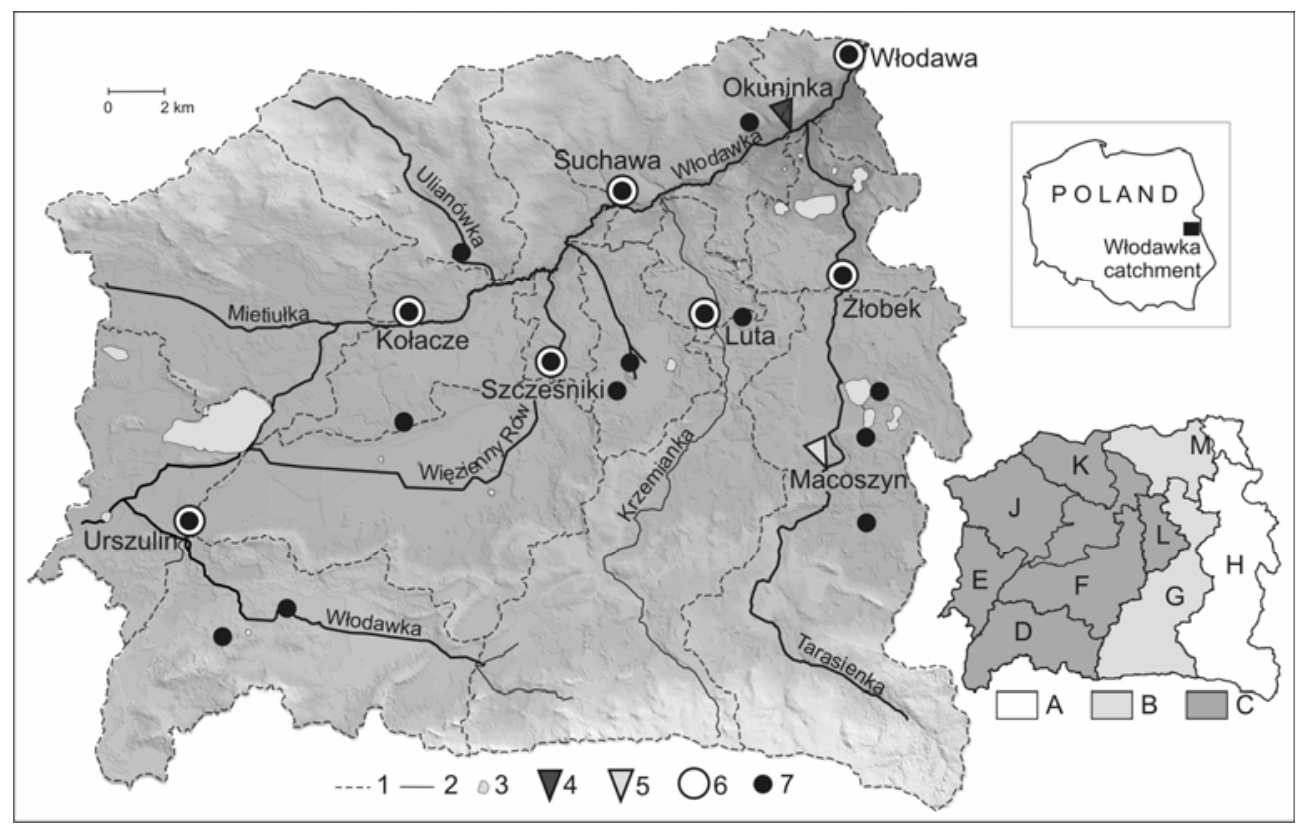

Fig. 1. Elementary catchments of the Włodawka River catchment and places of hydrological measurements; 1 - water divides, 2 - watercourses, 3 - lakes and reservoirs, 4 - water gauge of the Institute of Meteorology and Water Management, 5 - water gauge of the Department of Hydrography of UMCS, 6 - places of hydrological monitoring by the Department of Hydrography of UMCS, 7 - places of water sampling for physical and chemical analyses, $A$ - the Włodawka River catchment, $B$ - the Włodawka catchment as far as the Okuninka water gauge, $C$ - the Włodawka catchment as far as the Suchawa water gauge, $D-M$ - elementary catchments (Tab. 1) 
trict, contains organic accumulation plains separated by small sandbars of Pleistocene accumulation. In the north, the depression of the Lake District ends in Włodawa Hummock, while in the south there are several elevations formed on the convexities of the Cretaceous bedrock of the Chelm Hills. The longitudinal ramparts of eskers and kames separate a number of lowerings. This mosaic of convex forms and permanently or periodically wet lowering of the land has been drained by a dense network of drainage ditches.

The area of peatland in the Włodawka catchment amounts to $106.85 \mathrm{~km}^{2}$, and the size of the peat cover is $11.7 \%$, which is the highest percentage among all macroregions in Poland (LIPKA, 2000). Wetlands, permanently or temporarily excessively moistened, include, apart from peatland, slime areas, mineral floors of river valleys and inland hollows, the floating vegetation mat zone, etc. The area of wetlands in the studied catchment amounts to $224.78 \mathrm{~km}^{2}$.

Depending on the location of the wetland within the lowering and on the alimentation method, all hydrological types of wetland occur here: ombrogenic, topogenic, soligenic and fluviogenic ones (DEMBEK, 2004; DEMBEK et al., 2004; DEMBEK and OŚWIT, 1992; ŻUREK, 1987).

In spite of big transformations of the hydrosphere of the catchment, a large part of its area is legally protected. The western and south-western parts of the drainage basin are occupied by the Poleski National Park, and the eastern part - by the Sobiborski Landscape Park. The protected areas with a big share of water and swamp ecosystems are an important node in the ECONET network - the "Western Polesie" International Biosphere Reserve.

\section{RESEARCH METHODS}

The first stage consisted in creating a model of the land relief at a scale of 1:10,000. The model was used to demarcate the watershed zones, identify wetlands and the water gates which connect formerly drainless areas. As a result, 13 elementary catchments were distinguished, characterised by different morphometric features (Tab. 1, Fig. 1), share of wetlands (Fig. 2) and land use (Fig. 3). The degree of anthropogenic transformation of swampland was also determined and expressed through the density of the drainage network, among other things (Tab. 1).

A map of land use at a scale of 1:10,000 was compiled (Fig. 3), which was used in the assessment of the components of the water cycle (PASZCZYK and TURCZYŃSKI, 1996) in non-monitored catchments in hydrogenic areas and to compile a test water balance for the Włodawka catchment.

The analysis of the hydrometeorological conditions in the Włodawka catchment was based on the data of the IMGW from the meteorological station in Włodawa and from the water-gauging station on the Włodawka in Okuninka. Hydrological research also included own, patrol measurements of discharge in selected 
Table 1. Basic characteristics of elementary catchments in the Włodawka River catchment

\begin{tabular}{|c|c|c|c|c|c|c|c|c|}
\hline $\begin{array}{l}\text { Name of catchment } \\
\text { (symbol in Fig. 1) }\end{array}$ & 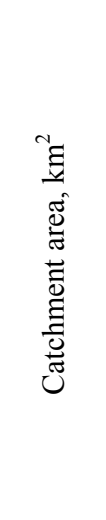 & 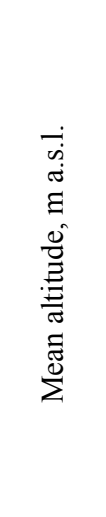 & 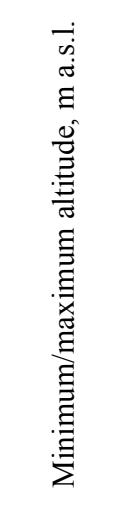 & 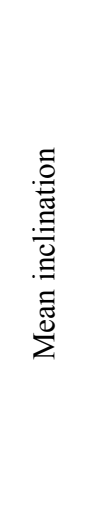 & 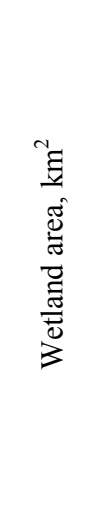 & 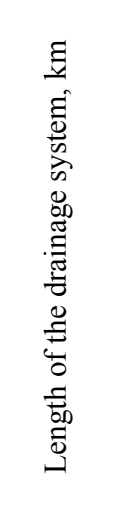 & 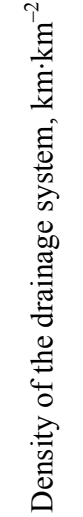 & 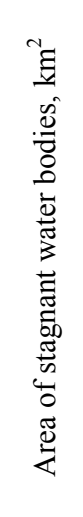 \\
\hline Włodawka (A) & 725,34 & 174.8 & $154 / 238$ & $\begin{array}{l}7.4 \% \\
4.2^{\circ}\end{array}$ & 224.78 & 1463.74 & 2.02 & 11.00 \\
\hline $\begin{array}{l}\text { Włodawka - Okunin- } \\
\text { ka (B) }\end{array}$ & 565.11 & 174.3 & $155 / 227$ & $\begin{array}{l}6.2 \% \\
3.5^{\circ}\end{array}$ & 179.31 & 1282.94 & 2.27 & 8.09 \\
\hline $\begin{array}{l}\text { Włodawka - Suchawa } \\
\text { (C) }\end{array}$ & 404.15 & 173.5 & $160 / 216$ & $\begin{array}{l}5.1 \% \\
2.9^{\circ}\end{array}$ & 149.82 & 1077.26 & 2.67 & 7.98 \\
\hline $\begin{array}{l}\text { Mietiułka (Kołacze) } \\
(\mathrm{J})\end{array}$ & 78.77 & 176.4 & $165 / 212$ & $\begin{array}{l}5.1 \% \\
2.9^{\circ}\end{array}$ & 27.06 & 220.20 & 2.80 & 2.11 \\
\hline Więzienny Rów (F) & 88.17 & 169.3 & $161 / 189$ & $\begin{array}{l}4.8 \% \\
2.8^{\circ}\end{array}$ & 46.58 & 397.71 & 4.51 & 0.15 \\
\hline $\begin{array}{l}\text { Więzienny Rów - } \\
\text { Szcześniki }\end{array}$ & 78.80 & 169.7 & $165 / 189$ & $\begin{array}{l}4.8^{\circ} \% \\
2.8^{\circ}\end{array}$ & 44.42 & 384.71 & 4.88 & 0.15 \\
\hline $\begin{array}{l}\text { Watercourse near } \\
\text { Dubeczno (L) }\end{array}$ & 24.23 & 167.3 & $161 / 178$ & $\begin{array}{l}4.9 \% \\
2.8^{\circ}\end{array}$ & 9.71 & 36.34 & 1.50 & 0.31 \\
\hline Kochanowskie (E) & 43.83 & 169.7 & $167 / 177$ & $\begin{array}{l}5.2 \% \\
3.0^{\circ}\end{array}$ & 22.65 & 136.97 & 3.13 & 5.16 \\
\hline Urszulin (D) & 75.48 & 178.0 & $169 / 216$ & $\begin{array}{l}6.0^{\circ} \% \\
3.4^{\circ}\end{array}$ & 25.98 & 118.87 & 1.57 & 0.23 \\
\hline Krzemianka (G) & 108.84 & 178.8 & $160 / 227$ & $\begin{array}{l}6.0^{\circ} \% \\
3.4^{\circ}\end{array}$ & 24.17 & 164.03 & 1.51 & 0.05 \\
\hline Krzemianka - Luta & 95.72 & 180.5 & $164 / 227$ & $\begin{array}{l}5.8^{\circ} \\
3.3^{\circ}\end{array}$ & 22.26 & 155.76 & 1.63 & 0.05 \\
\hline Tarasienka $(\mathrm{H})$ & 145.59 & 177.7 & $155 / 238$ & $\begin{array}{l}5.9 \% \\
3.4^{\circ}\end{array}$ & 42.74 & 162.82 & 1.12 & 2.95 \\
\hline Tarasienka - Żłobek & 120.43 & 180.7 & $162 / 238$ & $\begin{array}{c}5.9 \% \\
3.4^{\circ}\end{array}$ & 36.62 & 135.84 & 1.13 & 1.11 \\
\hline Ulanówka (K) & 44.12 & 181.5 & $163 / 207$ & $\begin{array}{c}5.7 \% \\
3.3^{\circ}\end{array}$ & 5.96 & 58.53 & 1.33 & 0.004 \\
\hline Lower Włodawka (M) & 66.75 & 169.9 & $154 / 200$ & $\begin{array}{l}4.9 \% \\
2.8^{\circ}\end{array}$ & 8.05 & 59.63 & 0.89 & 0.07 \\
\hline
\end{tabular}




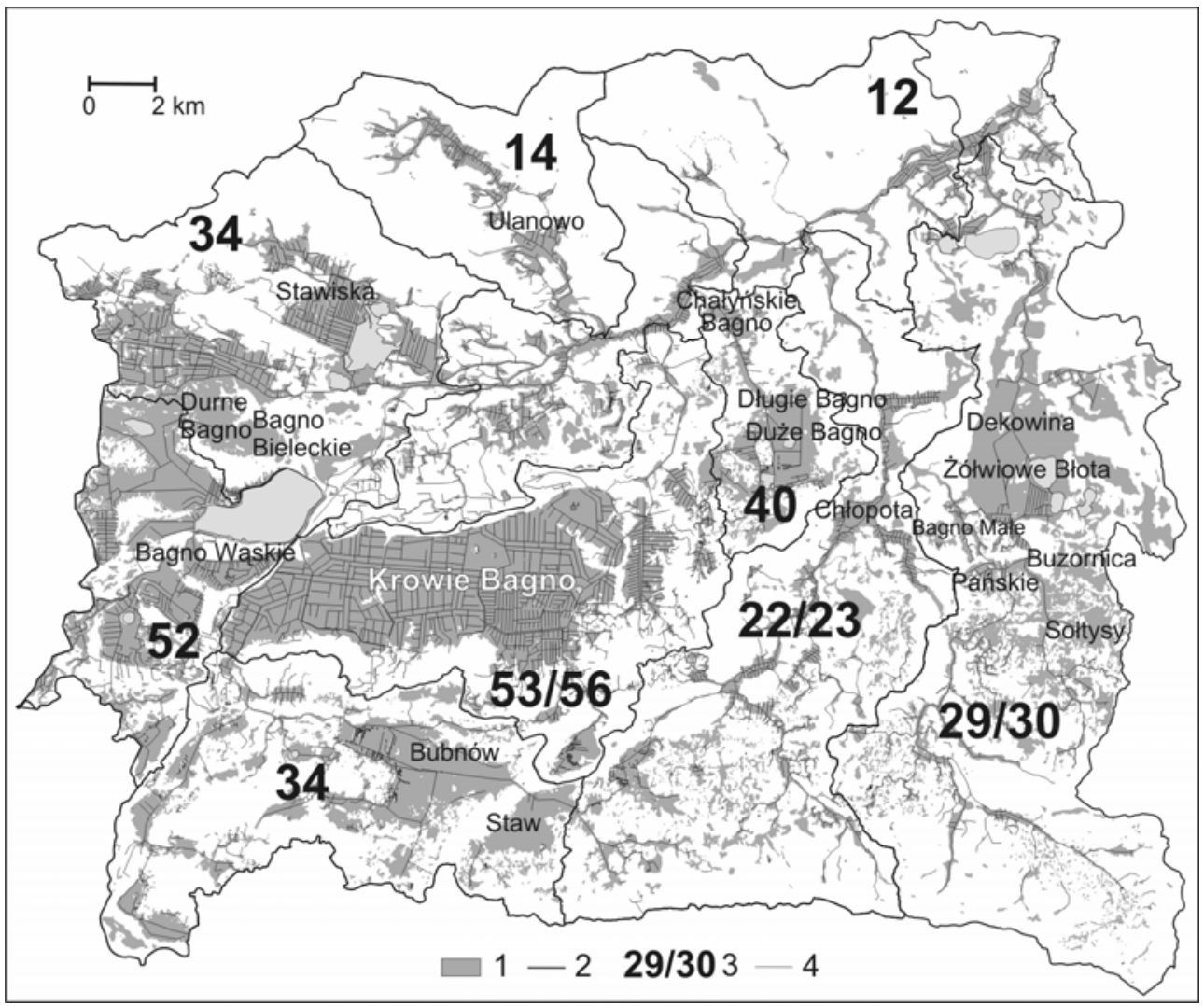

Fig. 2. Wetlands and their share in the area of elementary catchments of the Włodawka River catchment; 1 - wetlands, 2 - water divides of elementary catchments, 3 - percentage of wetlands (total catchment area/controlled catchment area), 4 - drainage ditches

profiles and water sampling for the purpose of physico-chemical analysis in the laboratory of the Department of Hydrography of UMCS in Lublin. Water samples were analysed for: reaction and proper electrolyte conductivity - using a Level $1 \mathrm{~m}$ by WTW inoLab; the concentration of anions and cations - using an ion chromatograph by Metrohm MIC 3; dissolved organic carbon (DOC) - with a Pastel UV spectrometer by Secoman company. Total nitrogen (TN) and total phosphorus (TP) were determined using a DR 2000 spectometer by Hach in non-filtered samples acidified with $\mathrm{H}_{2} \mathrm{SO}_{4}$ to $\mathrm{pH} \sim 2$ and $\mathrm{UV}$ mineralised with $\mathrm{H}_{2} \mathrm{O}_{2}$. In the process of the analysis, standard solutions by Merck and certified test material Nutrients RTCQCI-028 were used. 


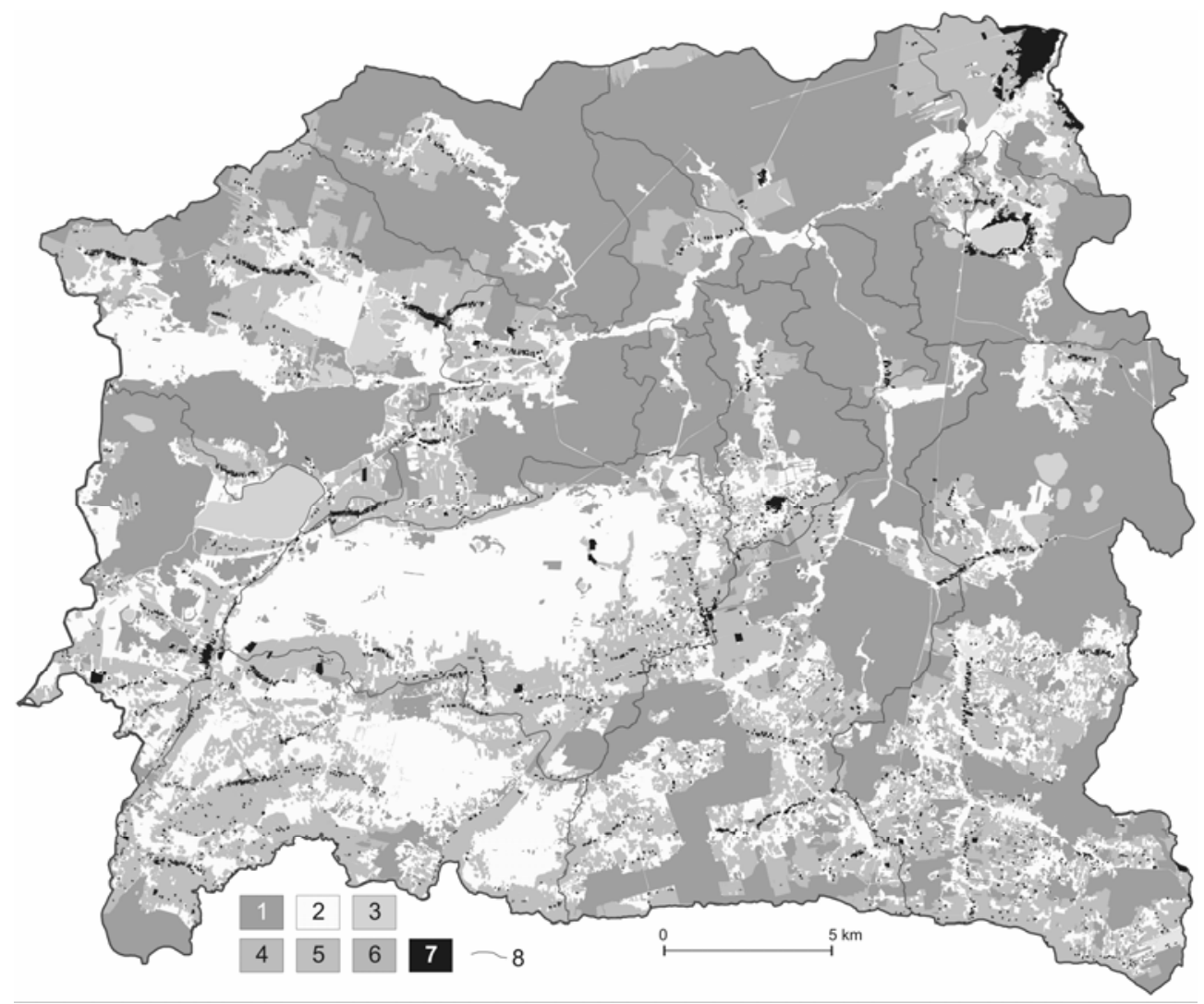

Fig. 3. Land use in the Włodawka River catchment; 1 - forests, 2 - meadows, pastures, peatland, 3 - water bodies, 4 - orchards, parks, trees, 5 - arable land, 6 - buildings, 7 - water divides, 8 - permanent wetlands

\section{RESULTS AND DISCUSSION}

The present-day drainage system in the Włodawka catchment (Fig. 2) is the result of melioration work carried out over a period of nearly three centuries. The Włodawka River functioned as a natural watercourse only in its lower section. A gradual incorporation of systems of drainage ditches which discharged the excessive amounts of water from large, originally drainless marsh complexes led to the formation of a common, very complex drainage system. Nowadays, the water network of the area is made up of non-regulated watercourses: the Włodawka, an unnamed stream in the vicinity of the Kochanowskie village, the Mietiułka (Kołacze), Więzienny Rów, Upper Włodawka (Urszulin), Krzemianka, Suchawa, Ulanówka and a stream near Dubeczno; artificial ditches, lakes and fishing ponds. The main recipient of the waters - the Włodawka is regulated along the entire 
length of its course, and the water resources in its wide valley are controlled with hydrotechnical devices.

On the basis of the analysis of maps and aerial photographs verified with field research, 1495 bodies in the Włodawka catchment were classified as permanent or periodic wetlands. The biggest ones, with compact limits (Fig. 2) are: Krowie Bagno $\left(36.9 \mathrm{~km}^{2}\right)$, the valley of the Middle Tarasienka with Żółwiowe Błota (26.6 $\mathrm{km}^{2}$ ), Durne Bagno, an area between Lake Długie and Wytycki Reservoir (23.2 $\mathrm{km}^{2}$ ), the valley of Middle and Lower Włodawka $\left(15.2 \mathrm{~km}^{2}\right)$, the valley of Upper and Middle Krzemianka $\left(11.9 \mathrm{~km}^{2}\right)$, Bagno Bubnów $\left(10.0 \mathrm{~km}^{2}\right)$, Dubeczno $(8.1$ $\mathrm{km}^{2}$ ) and Bagno Staw $\left(3.6 \mathrm{~km}^{2}\right)$.

Land use in the Włodawka catchment area is of a dual character (Fig. 3). In the north-western part of the basin, forests are prevalent, interspersed with islands of arable land, while in the south-west, arable land with a large share of meadows dominates. Meadows in the Włodawka catchment were established on dried peatland, which considerably reduced the area of permanent wetlands.

Quasi-natural permanent wetlands with a relatively undisturbed water cycle occupy about $40 \%$ of the original hydrogenic area (Fig. 3). The biggest transformations took place in the Więzienny Rów catchment comprising the Krowie Bagno complex. Natural water and peat ecosystems have been preserved here in narrow zones surrounding small lakes: Lubowierz, Lubowierzek, Laskie and Hańskie, which corresponds to a mere $4.3 \%$ of the original wetland. The elementary catchments of the Upper Włodawka down to Urszulin, the Dubeczyńskie, Kochanowskie and Tarasienka, where the area of permanent wetlands is more than half of the total wetland area, stand out against others. In the Urszulin catchment, two large complexes of Bagno Bubnów and Bagno Swamp remain as open peatland. Permanently water-logged areas mainly occur in the forests of the eastern part of the catchment. Forest wetland accounts for $64 \%$ of the hydrologically active wetland.

\section{HYDROLOGIC CHARACTERISTICS}

The average annual precipitation in the Włodawka catchment, determined on the basis of IMGW data for the period between 1984-2008 was $517 \mathrm{~mm}$, with extreme values at 370 and $651 \mathrm{~mm}$ registered respectively, in 2003 and 2001 (Fig. $4 \mathrm{~A})$. The mean annual value of evapotranspiration, calculated using the Kuzin method, amounted to $425 \mathrm{~mm}$ (from 352 to 487 ).

The mean annual runoff coefficient determined on the basis of discharge over the studied 25-year period amounted to $105 \mathrm{~mm}$, calculated from the balance difference between precipitation and evaporation - to $92 \mathrm{~mm}$, and calculated from a formula which accounted for land use (PASZCZYK and TURCZYŃSKI, 1996) - to $112 \mathrm{~mm}$ (Fig. 4B). 


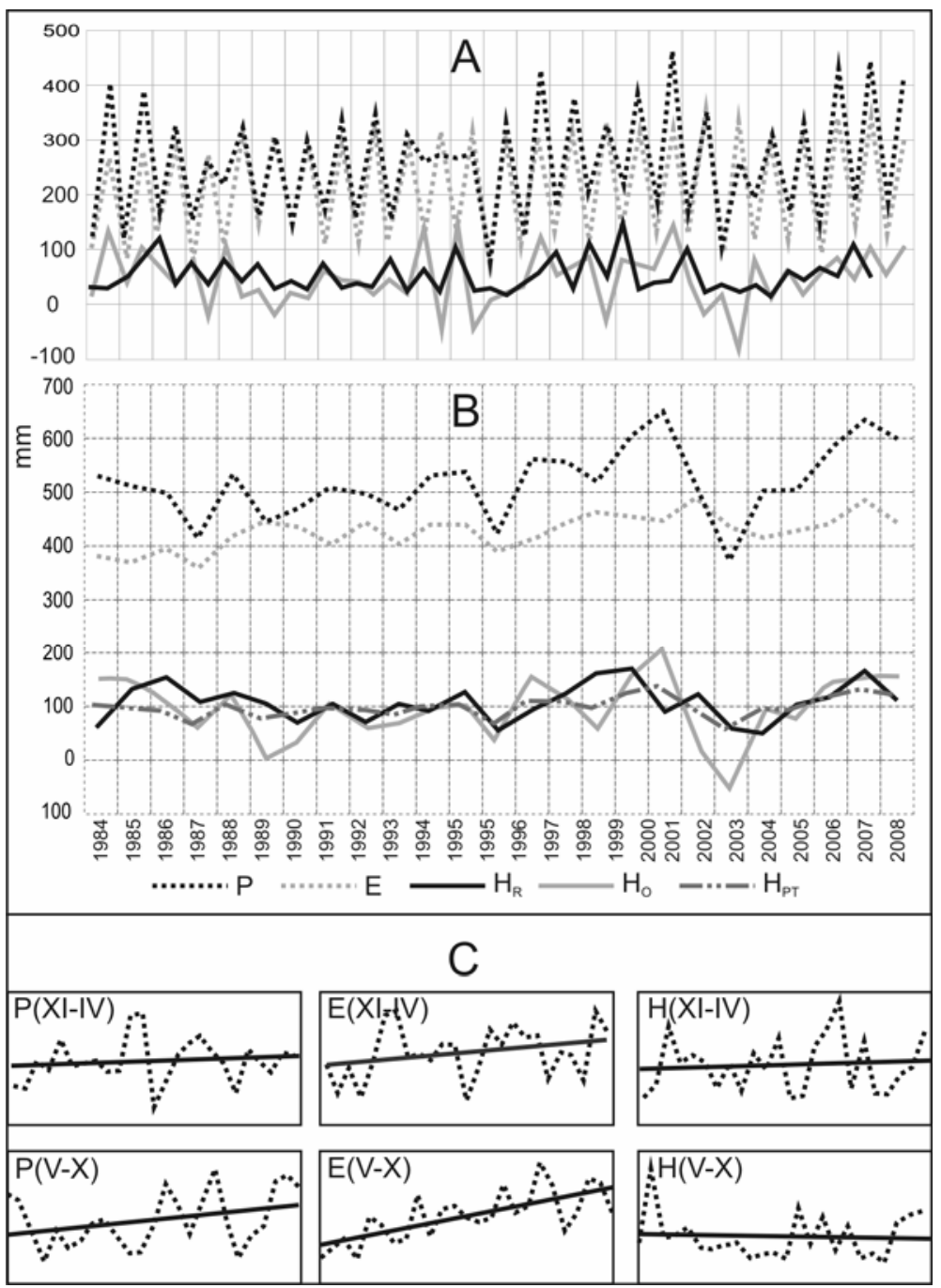

Fig. 4. Water balance components (1984-2008); $P$ - precipitation,

$E$ - evapotranspiration, $H_{R}$ - real runoff, $H_{o}$ - runoff calculated form balance equation $P-E, H P T$ - runoff calculated using PASZCZYK and TURCZYŃSKI formulae (1996) A - by half-years, B - annual values, C - trends of water balance components in half-years

The mean annual specific runoff in Okuninka had the value of 3.33 $\mathrm{dm}^{3} \cdot \mathrm{s}^{-1} \cdot \mathrm{km}^{-2}$, in the winter half-year it was $4.51 \mathrm{dm}^{3} \cdot \mathrm{s}^{-1} \cdot \mathrm{km}^{-2}$, while in the summer one $-2.14 \mathrm{dm}^{3} \cdot \mathrm{s}^{-1} \cdot \mathrm{km}^{-2}$. In the analysed multi-year period, extreme annual specific runoff values were 1.53 and $5.45 \mathrm{dm}^{3} \cdot \mathrm{s}^{-1} \cdot \mathrm{km}^{-2}$. The minimum monthly specific runoff of $0.40 \mathrm{dm}^{3} \cdot \mathrm{s}^{-1} \cdot \mathrm{km}^{-2}$ was observed in February 1996, and the maximum one - $20.81 \mathrm{dm}^{3} \cdot \mathrm{s}^{-1} \cdot \mathrm{km}^{-2}$ - in April 2000. The biggest monthly runoff variability 
caused by mid-winter thaws occurred in February, while in the summer months (June-September) it was a consequence of drought or heavy precipitation. This is confirmed by synoptic measurements carried out in September 2007 and 2008 (MICHALCZYK and GŁOWACKI, 2008), when specific runoff in the range of 1.1$-2.22(2007)$ and $0.11-1.21 \mathrm{dm}^{3} \cdot \mathrm{s}^{-1} \cdot \mathrm{km}^{-2}$ (2008) was registered in elementary catchments. In the same measurement periods, there was no runoff in the Upper Włodawka catchment - as far as the Urszulin profile.

In the analysed 25-year period, the following trends were observed: in the winter half-year, with a slight increase in evaporation, precipitation and runoff were stable (Fig. 4C). A small increase in precipitation in the summer half-year, concurrent with a considerable increase in evapotranspiration, led to a downward trend in runoff. A particularly serious water deficit occurred in 2003-2004 (Fig. 4B).

\section{PHYSICAL AND CHEMICAL PROPERTIES OF WATERS IN THE WŁODAWKA CATCHMENT}

Groundwaters and surface waters in the Włodawka catchment were characterised by a high hydrochemical diversity, depending on the lithological type of the deposits in the drainage zone, biochemical changes and anthropogenic transformation of the environment (Tab. 2). Waters from carbonate rocks, supplying the watercourses, were characterised by a near neutral reaction, high content of $\mathrm{HCO}_{3}$ and $\mathrm{Ca}$ ions, and their mineralization usually exceeded $500 \mathrm{mg} \cdot \mathrm{dm}^{-3}$. Waters taken from Pleistocene deposits had a $\mathrm{pH}$ ranging from weak acidic to neutral, a much lower content of $\mathrm{HCO}_{3}$ and $\mathrm{Ca}$ ions, and their mineralization varied from several dozen to several hundred $\mathrm{mg} \cdot \mathrm{dm}^{-3}$. In groundwaters, $\mathrm{HCO}_{3}-\mathrm{Ca}$ ions dominated, while the hydrochemical type of some water samples was also affected by the presence of sulphate and nitrate ions. The concentration of dissolved organic carbon (DOC) in the studied waters did not exceed $2 \mathrm{mg} \cdot \mathrm{dm}^{-3}$.

The physical and chemical properties of alimentation waters from wetlands reflected the specific character of the organogenic deposits environment. Waters from lowmoor and transitional moor were usually weakly acidic, rarely acidic, and showed low mineralization. Waters from the calciphilous peatbog (Bagno Bubnów) were characterised by a $\mathrm{pH}$ near neutral and a much higher mineralization. In peatbog waters, $\mathrm{HCO}_{3}-\mathrm{Ca}$ ions prevailed and the concentration of sodium, potassium, chlorides and sulphates was rarely higher than several $\mathrm{mg} \cdot \mathrm{dm}^{-3}$, and in the case of nitrates $-1 \mathrm{mg} \cdot \mathrm{dm}^{-3}$. A relatively high concentration of TN and low of TP was observed. In contrast, in waters from grassland formed on peatbog, the content of sulphates, nitrates and phosphates was a lot higher. High concentrations of DOC were characteristic of alimentation waters from organogenic areas (Fig. 5). 
Table 2. Physico-chemical properties of the Włodawka River waters in the river-mouth profile against surface and groundwaters, data for 2007-2008; location of water sampling sites Fig. 5A

\begin{tabular}{|c|c|c|c|c|c|c|c|c|c|}
\hline \multirow{3}{*}{ Index } & \multirow{3}{*}{ Unit } & \multirow{2}{*}{\multicolumn{2}{|c|}{$\begin{array}{l}\text { Groundwaters } \\
\text { (16 samples) }\end{array}$}} & \multirow{2}{*}{\multicolumn{2}{|c|}{$\begin{array}{l}\text { River waters } \\
\text { (34 samples) }\end{array}$}} & \multirow{2}{*}{\multicolumn{2}{|c|}{$\begin{array}{c}\text { Water runoff from } \\
\text { natural peatlands } \\
\text { (21 samples) }\end{array}$}} & \multicolumn{2}{|c|}{$\begin{array}{l}\text { The Włodawka } \\
\text { river mouth }\end{array}$} \\
\hline & & & & & & & & \multirow{2}{*}{$\begin{array}{l}\hat{8} \\
\text { ते } \\
\stackrel{\overrightarrow{0}}{\mathbf{2}} \\
\vec{N}\end{array}$} & \multirow{2}{*}{ 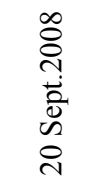 } \\
\hline & & $\begin{array}{l}\min \\
\max \end{array}$ & $\begin{array}{l}\text { average } \\
\text { median }\end{array}$ & $\begin{array}{l}\min \\
\max \end{array}$ & $\begin{array}{l}\text { average } \\
\text { median }\end{array}$ & $\begin{array}{l}\min \\
\max \end{array}$ & $\begin{array}{l}\text { average } \\
\text { median }\end{array}$ & & \\
\hline $\mathrm{pH}$ & - & $\begin{array}{l}5.88 \\
7.33\end{array}$ & $\begin{array}{l}6.59 \\
6.74\end{array}$ & $\begin{array}{l}6.82 \\
7.82\end{array}$ & $\begin{array}{l}7.34 \\
7.36\end{array}$ & $\begin{array}{l}5.45 \\
7.91\end{array}$ & $\begin{array}{l}6.71 \\
6.66\end{array}$ & 7.18 & 7.64 \\
\hline SEC & $\mu \mathrm{S} \cdot \mathrm{cm}^{-1}$ & $\begin{array}{l}146 \\
635\end{array}$ & $\begin{array}{l}295 \\
226\end{array}$ & $\begin{array}{l}179 \\
681\end{array}$ & $\begin{array}{l}389 \\
351\end{array}$ & $\begin{array}{c}66 \\
477\end{array}$ & $\begin{array}{l}204 \\
145\end{array}$ & 360 & 287 \\
\hline Alk. & $\mathrm{mval} \cdot \mathrm{dm}^{-3}$ & $\begin{array}{l}0.25 \\
5.35\end{array}$ & $\begin{array}{l}2.09 \\
1.78\end{array}$ & $\begin{array}{l}1.92 \\
6.65\end{array}$ & $\begin{array}{l}3.52 \\
2.32\end{array}$ & $\begin{array}{l}0.35 \\
4.60\end{array}$ & $\begin{array}{l}1.93 \\
1.08\end{array}$ & 3.26 & 2.55 \\
\hline $\mathrm{Cl}^{-}$ & $\mathrm{mg} \cdot \mathrm{dm}^{-3}$ & $\begin{array}{c}2.3 \\
15.6\end{array}$ & $\begin{array}{l}7.8 \\
6.7\end{array}$ & $\begin{array}{c}3.6 \\
12.7\end{array}$ & $\begin{array}{l}7.6 \\
7.5\end{array}$ & $\begin{array}{l}2.0 \\
9.1\end{array}$ & $\begin{array}{l}3.9 \\
3.6\end{array}$ & 7.6 & 6.5 \\
\hline $\mathrm{SO}_{4}^{2-}$ & $\mathrm{mg} \cdot \mathrm{dm}^{-3}$ & $\begin{array}{c}9.2 \\
65.8\end{array}$ & $\begin{array}{l}29.6 \\
22.5\end{array}$ & $\begin{array}{c}7.2 \\
65.4\end{array}$ & $\begin{array}{l}23.7 \\
20.1\end{array}$ & $\begin{array}{c}0.3 \\
10.4\end{array}$ & $\begin{array}{l}2.1 \\
1.0\end{array}$ & 18.1 & 15.7 \\
\hline $\mathrm{NO}_{3}^{-}$ & $\mathrm{mg} \cdot \mathrm{dm}^{-3}$ & $\begin{array}{c}3.2 \\
52.4\end{array}$ & $\begin{array}{l}19.6 \\
10.8\end{array}$ & $\begin{array}{c}0.6 \\
19.3\end{array}$ & $\begin{array}{l}4.9 \\
3.3\end{array}$ & $\begin{array}{c}<0.1 \\
0.3\end{array}$ & $\begin{array}{l}0.2 \\
0.1\end{array}$ & 2.6 & 4.6 \\
\hline $\mathrm{NO}_{2}^{-}$ & $\mathrm{mg} \cdot \mathrm{dm}^{-3}$ & $\begin{array}{l}0.009 \\
0.263\end{array}$ & $\begin{array}{l}0.073 \\
0.012\end{array}$ & $\begin{array}{l}0.005 \\
0.113\end{array}$ & $\begin{array}{l}0.031 \\
0.028\end{array}$ & $\begin{array}{c}<0.001 \\
0.012\end{array}$ & $\begin{array}{l}0.003 \\
0.002\end{array}$ & 0.037 & 0.012 \\
\hline $\mathrm{Ca}^{2+}$ & $\mathrm{mg} \cdot \mathrm{dm}^{-3}$ & $\begin{array}{l}28.5 \\
147\end{array}$ & $\begin{array}{c}84.1 \\
81\end{array}$ & $\begin{array}{c}47.3 \\
141\end{array}$ & $\begin{array}{l}82.7 \\
71.6\end{array}$ & $\begin{array}{c}13 \\
100\end{array}$ & $\begin{array}{l}43 \\
23\end{array}$ & 72.1 & 54.4 \\
\hline $\mathrm{Mg}^{2+}$ & $\mathrm{mg} \cdot \mathrm{dm}^{-3}$ & $\begin{array}{l}1.5 \\
3.9\end{array}$ & $\begin{array}{l}2.3 \\
1.9\end{array}$ & $\begin{array}{l}1.6 \\
3.9\end{array}$ & $\begin{array}{l}2.9 \\
2.9\end{array}$ & $\begin{array}{l}0.6 \\
3.6\end{array}$ & $\begin{array}{l}1.8 \\
1.7\end{array}$ & 2.6 & 2.5 \\
\hline $\mathrm{Na}^{+}$ & $\mathrm{mg} \cdot \mathrm{dm}^{-3}$ & $\begin{array}{c}1.5 \\
17.6\end{array}$ & $\begin{array}{l}4.4 \\
4.3\end{array}$ & $\begin{array}{l}3.0 \\
6.5\end{array}$ & $\begin{array}{l}5.0 \\
5.2\end{array}$ & $\begin{array}{l}1.0 \\
3.3\end{array}$ & $\begin{array}{l}1.9 \\
1.8\end{array}$ & 5.4 & 5.1 \\
\hline $\mathrm{K}^{+}$ & $\mathrm{mg} \cdot \mathrm{dm}^{-3}$ & $\begin{array}{l}0.8 \\
4.6\end{array}$ & $\begin{array}{l}1.9 \\
1.1\end{array}$ & $\begin{array}{l}0.5 \\
2.3\end{array}$ & $\begin{array}{l}1.4 \\
1.3\end{array}$ & $\begin{array}{l}0.2 \\
1.3\end{array}$ & $\begin{array}{c}0.7 \\
0.85\end{array}$ & 1.3 & 1.1 \\
\hline $\mathrm{NH}_{4}$ & $\mathrm{mg} \cdot \mathrm{dm}^{-3}$ & $\begin{array}{l}0.01 \\
0.15\end{array}$ & $\begin{array}{l}0.07 \\
0.05\end{array}$ & $\begin{array}{l}0.05 \\
1.85\end{array}$ & $\begin{array}{l}0.49 \\
0.47\end{array}$ & $\begin{array}{l}0.10 \\
1.30\end{array}$ & $\begin{array}{l}0.45 \\
0.31\end{array}$ & 0.42 & 0.23 \\
\hline DOC & $\mathrm{mg} \cdot \mathrm{dm}^{-3}$ & $\begin{array}{c}<1.0 \\
2.8\end{array}$ & $\begin{array}{l}1.8 \\
2.1\end{array}$ & $\begin{array}{c}10.4 \\
47\end{array}$ & $\begin{array}{l}21.7 \\
20.8\end{array}$ & $\begin{array}{c}8.2 \\
48.5\end{array}$ & $\begin{array}{l}22.6 \\
16.8\end{array}$ & 24.2 & 18.2 \\
\hline $\mathrm{TN}$ & $\mathrm{mg} \cdot \mathrm{dm}^{-3}$ & $\begin{array}{c}0.8 \\
12.0\end{array}$ & $\begin{array}{l}4.6 \\
1.6\end{array}$ & $\begin{array}{l}0.95 \\
5.80\end{array}$ & $\begin{array}{l}2.09 \\
1.67\end{array}$ & $\begin{array}{l}0.53 \\
5.12\end{array}$ & $\begin{array}{l}2.01 \\
2.25\end{array}$ & 1.47 & 1.75 \\
\hline TP & $\mathrm{mg} \cdot \mathrm{dm}^{-3}$ & $\begin{array}{l}0.02 \\
0.27\end{array}$ & $\begin{array}{l}0.10 \\
0.08\end{array}$ & $\begin{array}{l}0.09 \\
0.41\end{array}$ & $\begin{array}{l}0.29 \\
0.26\end{array}$ & $\begin{array}{l}0.01 \\
0.12\end{array}$ & $\begin{array}{l}0.05 \\
0.04\end{array}$ & 0.22 & 0.36 \\
\hline
\end{tabular}

Explanations: SEC - specific electrolytic conductivity at $25^{\circ} \mathrm{C}$, Alk. - alkalinity, DOC - dissolved organic carbon, $\mathrm{TN}$ - total nitrogen, $\mathrm{TP}$ - total phosphorus. 


\section{RUNOFF OF DISSOLVED ORGANIC CARBON, NITROGEN AND PHOSPHORUS}

Hydrochemical and hydrometric material was a basis for the evaluation of the DOC, N and P runoff from the Włodawka catchment in 2007-2008 (Tab. 3, 4) and for the calculation of momentary outflow in September 2007 and June 2008 (Fig. 5). The results of the calculations indicate a high level of DOC being carried away in the waters of the Włodawka both in the annual runoff and on the basis of momentary flow measurements. Compact hydrogenic areas were the main source of the organic carbon supplied to river waters - over $90 \%$ of the DOC carried out by the river system. As for nitrogen runoff in the Włodawka catchment, what influenced the level of the runoff were both the drainage of organogenic deposits and the drainage of mineral deposits - particularly those used as cropland or built-up areas. The phosphorus runoff was shaped by the presence of degraded peatbog areas and built-up areas.

Table 3. Runoff of dissolved organic carbon (DOC) in the Włodawka River water in 2007-2008 ${ }^{1)}$

\begin{tabular}{l|c|c|c|c|c}
\hline \multirow{2}{*}{ Balance area } & \multicolumn{4}{c|}{ Outflow of DOC } & $\begin{array}{c}\text { \% share of DOC } \\
\text { in outflow from } \\
\text { catchment }\end{array}$ \\
\cline { 2 - 5 } & $\mathrm{t} \cdot \mathrm{y}^{-1}$ & $\mathrm{t} \cdot \mathrm{y}^{-1} \cdot \mathrm{km}^{-2}$ & $\mathrm{mg} \cdot \mathrm{s}^{-1}$ & $\mathrm{mg} \cdot \mathrm{s}^{-1} \cdot \mathrm{km}^{-2}$ & 100 \\
\hline $\begin{array}{l}\text { The Włodawka catch- } \\
\text { ment - river-mouth }\end{array}$ & 2544 & 3.51 & 80678 & 111.2 & 9.4 \\
$\begin{array}{l}\text { Mineral deposits } \\
\begin{array}{l}\text { Organogenic deposits } \\
\text { and other sources }\end{array}\end{array}$ & 240 & 0.49 & 7540 & 15.4 & 90.6 \\
\hline
\end{tabular}

1) Adopted for calculation: total discharge at Włodawa water gauge $3.77 \mathrm{~m}^{3} \cdot \mathrm{s}^{-1}$, DOC content in the Włodawka waters (mouth water gauge) $-21.4 \mathrm{mg} \cdot \mathrm{dm}^{-3}$, DOC concentration from mineral deposits drainage $-2 \mathrm{mg} \cdot \mathrm{dm}^{-3}$, level of DOC outflow from wetland is the balance difference.

Table 4. Average river outflow of nitrogen and phosphorus from the Włodawka River catchment in 2007-2008 ${ }^{1)}$

\begin{tabular}{l|r|r|c|c}
\hline \multicolumn{1}{c|}{ Element } & \multicolumn{1}{c}{$\mathrm{t} \cdot \mathrm{y}^{-1}$} & $\mathrm{mg} \cdot \mathrm{s}^{-1}$ & $\mathrm{t} \cdot \mathrm{y}^{-1} \cdot \mathrm{km}^{-2}$ & $\mathrm{mg} \cdot \mathrm{s}^{-1} \cdot \mathrm{km}^{-2}$ \\
\hline Nitrogen & 246.6 & 7842 & 0.34 & 10.80 \\
Phosphorus & 30.9 & 980 & 0.04 & 1.35 \\
\hline
\end{tabular}

${ }^{1)}$ Total discharge $-3.77 \mathrm{~m}^{3} \cdot \mathrm{s}^{-1}, \mathrm{TN}-2.08 \mathrm{mg} \cdot \mathrm{dm}^{-3}, \mathrm{TP}-0.26 \mathrm{mg} \cdot \mathrm{dm}^{-3}$. 

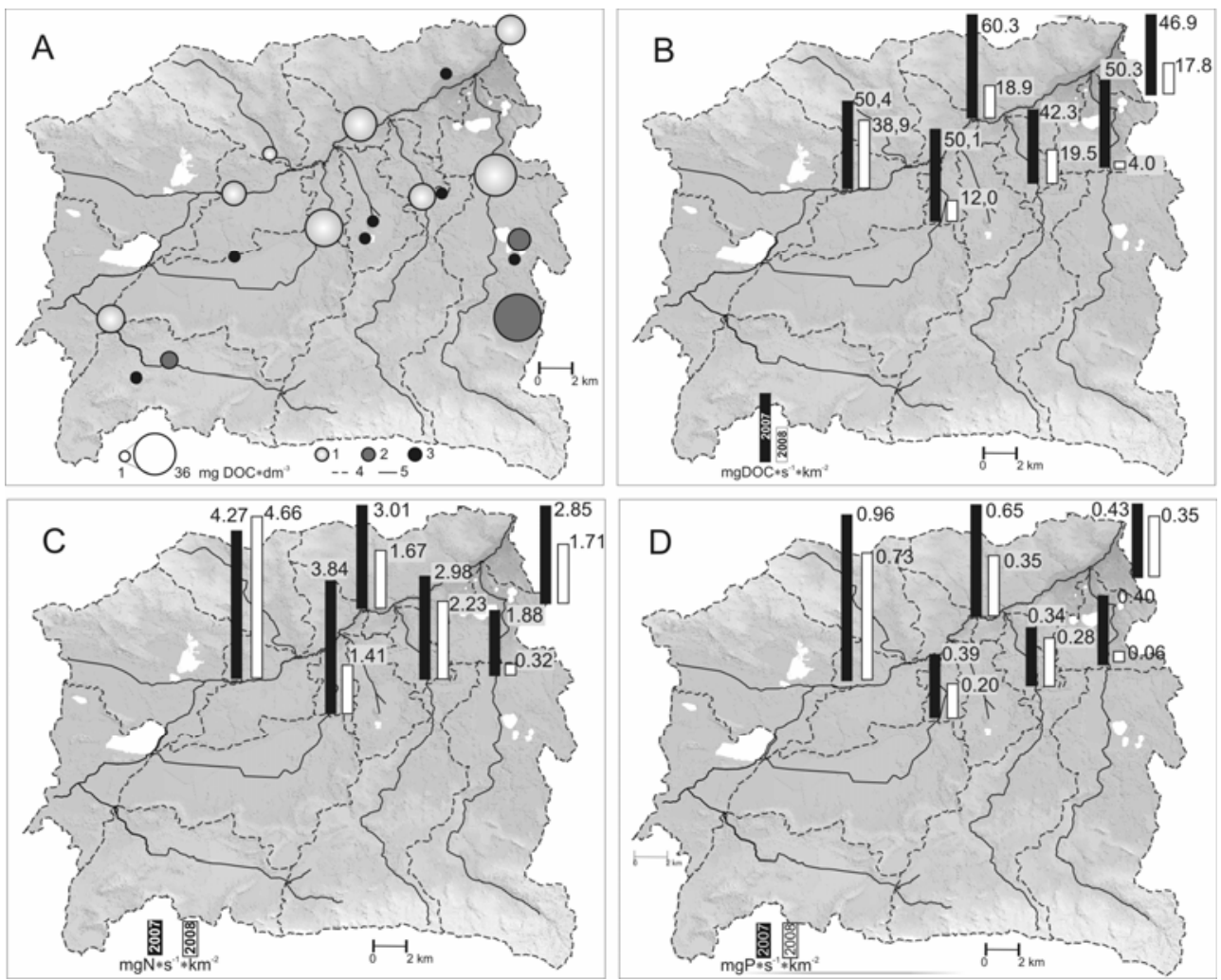

Fig. 5. Content of organic carbon (A: 1 - watercourses, 2 - peatlands, 3 - groundwaters) in the Włodawka River waters and outflow of DOC (B), nitrogen (C), phosphorus (D) during summer measurements in 2007-2008

\section{CONCLUSIONS}

1. The Włodawka River catchment of an area of $725 \mathrm{~km}^{2}$ is a complex drainage system which consists of 13 elementary catchments. The catchment formed as a result of the process of connecting numerous drainless wetlands into a hydrologically cohesive system. They play the role of water reservoirs which safeguard the functioning of the main river, and at the same time add to the environmental value of the Poleski National Park, its buffer zone, and the Sobiborski Landscape Park, which together make up the International Biosphere Reserve. The morphometry, geological structure and land use in the wetlands show high diversification, which is reflected in the complex water cycle.

2. Water-logged areas occupy $31 \%$ of the catchment area, and in elementary catchment their share ranges from 12 to $56 \%$. They are cut by a network of drain- 
age ditches, whose mean density amounts to $2 \mathrm{~km} \cdot \mathrm{km}^{-2}$, in elementary catchments - nearly $5 \mathrm{~km} \cdot \mathrm{km}^{-2}$, and in wetlands $-8.5 \mathrm{~km} \cdot \mathrm{km}^{-2}$ (Krowie Bagno).

3. Mean specific runoff in the studied area was $3.33 \mathrm{dm}^{3} \cdot \mathrm{s}^{-1} \mathrm{~km}^{-2}$ in 1984 -2008. Momentary specific runoff in some catchments decreased to $0.1 \mathrm{dm}^{3} \cdot \mathrm{s}^{-1}$ $\cdot \mathrm{km}^{-2}$ in summer periods. A permanent runoff from wetlands was observed at that time.

4. The waters of the Włodawka and its tributaries were found to have a high content of organic carbon $\left(8-36 \mathrm{mg} \cdot \mathrm{dm}^{-3}\right)$. In 2007-2008, an average of $2,436 \mathrm{t}^{-} \mathrm{y}^{-1}$ of DOC was carried away from the Włodawka catchment, $90 \%$ of which - from organogenic areas. Mean nitrogen runoff in 2007-2008 amounted to $237 \mathrm{t} \cdot \mathrm{y}^{-1}$, and phosphorus runoff - to $21.6 \mathrm{t} \cdot \mathrm{y}^{-1}$.

5. Hydrotechnical measures aimed at slowing the runoff and retaining water in the catchment are recommended. However, due to the high eutrophic potential of river waters, the construction of large storage reservoirs in the Włodawka catchment will affect adversely the quality of the waters.

6 . The findings of the study reveal the complexity of the water cycle system in the Włodawka catchment and the decisive role of wetlands in shaping the quantity and quality of the water runoff. Therefore, efficient water management requires the organisation of a permanent system of hydrologic and hydrochemical monitoring which would encompass the Włodawka River and its elementary catchments.

\section{REFERENCES}

1. BorowieC J., 1990. Torfowiska regionu Lubelskiego. (Peatlands of the Lublin region). Pr. Wydz. Nauk Ziemi Nauk Górn. Monogr., 3. Warszawa, LTN, PWN: 348.

2. ChURSKi Z., 1993. Zmiany hydrologiczne i przestrzenne obszarów podmokłych. W: Przemiany stosunków wodnych w Polsce w wyniku procesów naturalnych i antropogenicznych. (Hydrological and spatial changes in peatlands. In: Transformations of water relations in Poland due to the natural and anthropogenic processes). Ed. I. Dynowska. Kraków, UJ: 206-210.

3. DEMBEK W., OŚwIT J., 1992. Rozpoznawanie warunków hydrologicznego zasilania siedlisk mokradłowych. W: Hydrogeniczne siedliska wilgotnościowe. (Recognising hydrologic conditions of wetland recharge. In: Hydrogenic habitats). Bibl. Wiad. IMUZ, 79: 15-38.

4. Dembek W., Pawlaczyk P., Sienkiewicz J., DzierŻa P., 2004. Obszary wodno-błotne w Polsce. (Wetlands in Poland). Ed. W. Dembek. Falenty, Wydaw. IMUZ: 76.

5. Funkcjonowanie ekosystemów wodno-błotnych w obszarach chronionych Polesia (Functioning of wetland ecosystems in protected areas of Podlasie), 1996. Ed. S. Radwan. Lublin, AR, PPN, PTH, Wydaw. UMCS: 152.

6. IlNiCKi P., 2002. Torfowiska i torf. (Peatland and peat). Poznań, Wydaw. AR: 606.

7. LiPKA K., 2000. Torfowiska w dorzeczu Wisły jako element środowiska przyrodniczego. (Peatlands in the Vistula drainage basin as an element of the natural environment). Zesz. Nauk. AR Krak. Pr. Habil., 255: 148.

8. MichalczyK Z., 1998. Stosunki wodne Pojezierza Łęczyńsko-Włodawskiego. W: Jeziora Łęczyńsko-Włodawskie. Monografia przyrodnicza. (Water relations in Łęczyńsko-Włodawskie Lakeland. In: Łęczyńsko-Włodawskie lakes. Environmental monograph). Bibl. Monitor. Środ. Lublin, UMCS, PIOŚ: 55-71. 
9. Michalczyk Z., TuRCZYŃSKi M., DAwidek J., 1999. Wody powierzchniowe. W: Ekosystemy wodne i lądowe Sobiborskiego Parku Krajobrazowego i ich ochrona. (Surface waters. In: Aquatic and terrestrial ecosystems of the Sobiborski Landscape Park and their protection). Ed. W. Wojciechowska. Lublin, Wydaw. KUL: 31-61.

10. Michalczyk Z., GŁowAcki S., 2008. The diversificaton of water outflow in Pojezierze Łęczyńsko-Włodawskie. TEKA Kom. Ochr. Kszt. Środ. Przyr., Va. Lublin: 70-79.

11. MiĘSIAK-WÓJCIK K., 2009. Rola mokradła pojeziernego w zasilaniu rzeki (Pojezierze Łęczyńsko-Włodawskie). W: Zasoby i ochrona wód. Obieg wody i materii w zlewniach rzecznych. (The role of lacustrine wetland in river recharge (Łęczyńsko-Włodawskie Lakeland). In: Water resources and protection. Water and matter cycling in river catchments). Ed. R. Bogdanowicz, J. Fac-Beneda. Gdańsk, Wydaw. FRUG: 177-184.

12. PASZCZYK J., TuRCZYŃSKi M., 1996. Obszary hydrogeniczne Pojezierza Łęczyńsko-Włodawskiego. W: Funkcjonowanie ekosystemów wodno-błotnych w obszarach chronionego Polesia. (Hydrogenic areas of Łęczyńsko-Włodawskie Lakeland. In: Functioning of wetland ecosystems in protected areas of Podlasie). Ed. S. Radwan. Lublin, Wydaw. UMCS: 23-26.

13. Polesie Lubelskie (Lublin Polesie), 1963. Ed. T. Wilgat. Lublin, Wydaw. Lubelskie: 207.

14. SPOSÓB J., TURCZYŃSKi M., 2009. Przekształcenia obszarów bezodpływowych w zlewnie o wymuszonym obiegu wody - Pojezierze Łęczyńsko-Włodawskie. W: Zasoby i ochrona wód. Obieg wody i materii w zlewniach rzecznych. (Transformation of undrained areas into catchments of imposed water circulation - Łęczyńsko-Włodawskie Lakeland. In: Water resources and protection. Water and matter cycling in river catchments). Eds R. Bogdanowicz, J. Fac-Beneda. Gdańsk, Wydaw. FRUG: 111-121.

15. ŻUREK S., 1987. Złoża torfowe Polski na tle stref torfowiskowych Europy (Peat deposits in Poland in relation to European peatland zones). Dokum. Geogr. IGiPZ PAN, 4: 84.

\section{STRESZCZENIE}

\section{Ocena hydrologicznej roli obszarów podmokłych w dorzeczu Włodawki (Polesie Lubelskie)}

Słowa kluczowe: cechy fizyczno-chemiczne, hydrologia, obszary podmokte, Polesie Lubelskie

Zlewnia Włodawki o powierzchni $725 \mathrm{~km}^{2}$ została uformowana przede wszystkim przez połączenie wielu podmokłych obszarów bezodpływowych w spójny hydrologicznie system. Składa się on z 13 zlewni cząstkowych. Obszary podmokłe zajmują $31 \%$ zlewni, a w zlewniach cząstkowych ich udział wynosi od 12 do 56\%. Niektóre z nich stanowią cenne przyrodniczo fragmenty Poleskiego Parku Narodowego, jego otuliny oraz Sobiborskiego Parku Krajobrazowego, tworzących Międzynarodowy Rezerwat Biosfery. Ich morfometria, budowa geologiczna oraz użytkowanie ziemi wykazują duże zróżnicowanie, co przejawia się złożonym obiegiem wody. Badane zlewnie na znacznych przestrzeniach porozcinane są siecią rowów melioracyjnych, których średnia gęstość wynosi $2 \mathrm{~km} \cdot \mathrm{km}^{-2}$, osiagając w zlewniach cząstkowych wartość około $5 \mathrm{~km} \cdot \mathrm{km}^{-2}$, a w obrębie obszarów podmokłych nawet $8,5 \mathrm{~km} \cdot \mathrm{km}^{-2}$ (Krowie Bagno). 
Średni odpływ jednostkowy w zlewni Włodawki w latach 1984-2008 wynosił $3,33 \mathrm{dm}^{3} \cdot \mathrm{s}^{-1} \mathrm{~km}^{-2}$. Chwilowe odpływy jednostkowe w okresach letnich na terenie niektórych zlewni zmniejszają się do $0,1 \mathrm{dm}^{3} \cdot \mathrm{s}^{-1} \cdot \mathrm{km}^{-2}$. Trwały odpływ zarejestrowano wówczas z obszarów podmokłych.

W wodach rzeki Włodawka i jej dopływów stwierdzono dużą zawartość węgla organicznego $\left(8-36 \mathrm{mg} \cdot \mathrm{dm}^{-3}\right)$. Ze zlewni Włodawki odprowadzane było w latach 2007-2008 przeciętnie $2436 \mathrm{t} \cdot \mathrm{rok}^{-1}$ DOC, z czego ponad $90 \%$ pochodzi z obszarów organogenicznych. Średni odpływ azotu w latach 2007-2008 wynosił $237 \mathrm{t} \cdot \mathrm{rok}^{-1}$, a fosforu $21,6 \mathrm{t} \cdot \mathrm{rok}^{-1}$.

Wyniki badań wskazują na złożony system krążenia wody w zlewni Włodawki oraz na decydujący wpływ obszarów podmokłych w kształtowaniu jej ilości i jakości. W tej sytuacji racjonalne gospodarowanie wodą wymaga zorganizowania stałej sieci monitoringu hydrologicznego i hydrochemicznego, obejmującego Włodawkę i jej zlewnie cząstkowe, a ewentualne zabiegi hydrotechniczne powinny doprowadzać do spowolnienia odpływu i zatrzymywania wody w zlewni. Jednakże ze względu na znaczny potencjał eutroficzny wód rzecznych budowa dużych zbiorników retencyjnych na badanym obszarze będzie wpływała niekorzystnie na jakość wód.

Reviewers:

Prof. Waldemar Mioduszewski

Prof. Tomasz Okruszko 